\title{
SISTEM PENDUKUNG KEPUTUSAN KINERJA DOSEN MENGGUNAKAN METODE ANALYTICAL NETWORK PROCESS (ANP) PADA UNIVERSITAS
}

\author{
NAHOT FRASTIAN \\ DONA KATARINA \\ HERYATI \\ Program Studi Informatika \\ Fakultas Teknik dan Ilmu Komputer \\ Universitas Indraprasta PGRI \\ Jl. Nangka No. 58 C, Tanjung Barat, Jagakarsa, Jakarta Selatan 12530 \\ Email: nahotfrastian@gmail.com, dona.katrin@gmail.com, erymatematika@gmail.com
}

\begin{abstract}
Information technology continues to innovate and has the opportunity to grow further. One of the developments in information technology can be used as a means of performance evaluation is the Analytical Network Process (ANP) method. The assessment technique in this study is based on an assessment technique with a weighting assessment rule with a percentage distribution and a clearer weighting assessment rule. The Analytic Network Process (ANP) and Super Decision Software methods can be used to assess the performance of lecturers at the University. Lecturer performance appraisal process consists of several assessment criteria namely Pedagogy, Professional, Personality, and Social. The method used in sampling is a purposive sample (intentionally) with the best 5 to 10 lecturers that will be assessed by students. Respondents in this case students were taken randomly. Lecturer performance is weighted to produce a percentage for lecturer performance appraisal. This research resulted in a system in the form of percentage assessment or performance ranking of lecturers, this needs to be done so that research can produce an optimal decision that can be used as a decision support system as an assessment of the performance of lecturers at the university.
\end{abstract}

Keywords: decision support system, analytical network process (ANP), lecturer.

\section{PENDAHULUAN}

Kemajuan teknologi informasi semakin pesat, pengambilan keputusan berbasis teknologi misalnya dapat menghasilkan sistem kinerja dosen yang cerdas. Proses dalam menilai kinerja berdasarkan kompetensi kriteria yang bersifat kuantitatif misalkan kriteria Profesional, dosen dapat menggunakan data yang tersedia, yaitu berupa lembar kinerja dosen dari universitas atau angket. Semua kriteria dalam penelitian ini diolah menggunakan Software Super Decision. Sedangkan metode ANP dapat dimanfaatkan menghasilkan sistem pengambilan keputusan salah satunya untuk menentukan persoalan dalam penentuan kinerja dosen. Menjadikan sistem kinerja dosen atau penilai dalam memilih kinerja dosen secara obyektif.

Batasan masalah penelitian hanya pada penilaian kinerja dosen rumpun ilmu Teknik Informatika pada Universitas dan menggunakan pendekatan metode ANP sebagai berikut: 1). Penentuan penilaian kriteria kinerja dosen hanya pada kemampuan pedagogik, profesional, kepribadian dan social. 2). Sampel pada penelitian ini hanya menggunakan 10 (Sepuluh) dosen yang dianggap memiliki kompetensi terbaik oleh prodi Teknik Informatika di Universitas. 3). Hanya terdapat empat kriteria dan setiap kriteria hanya terdiri dari 4 (empat) sampai dengan 5 (lima) sub kriteria yang sudah ditentukan oleh peneliti.

\section{Analytic Network Process (ANP)}

Analytic Network Process adalah sebagian metode yang dapat merepresentasikan kepentingan berbagai pihak dengan pertimbangan saling terkait antar kriteria dan sub kriteria. 
Metode ini awalnya dikembangkan oleh Thomas L. Pada tahun 70-an. Menurut Saaty, L. Thomas (1993), Proses Hirarki Analitik untuk mengorganisasikan informasi dan judgment dalam memilih alternatif yang paling disukai. Dengan menggunakan AHP, Sebuah masalah yang akan diselesaikan sangat dapat direpresentasikankan untuk mengambil keputusan yang efektif atas persoalan tersebut. Masalah yang kompleks dapat disederhanakan proses pengambilan keputusannya. Tingkatan dalam ANP disebut cluster yang dapat memiliki beberapa kriteria dan alternatif di dalamnya, yang disebut simpul.

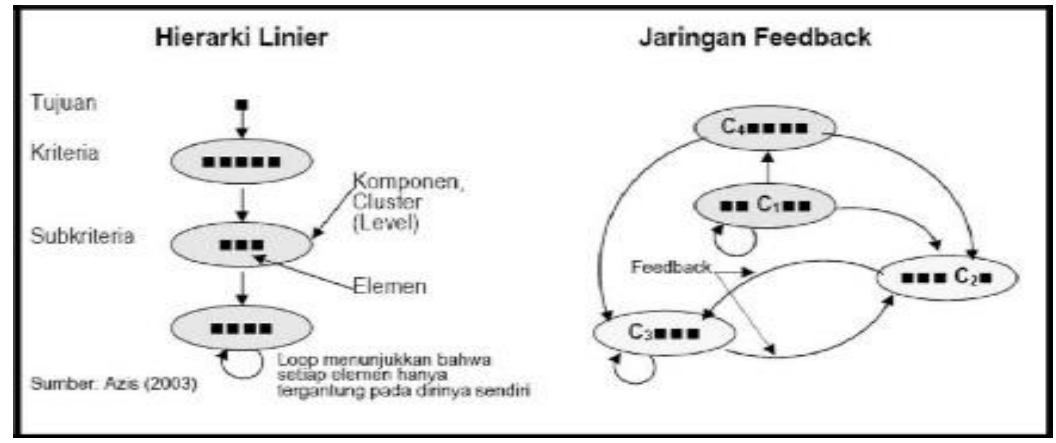

Gambar 1. Hasil perbandingan Hierarki Linier dengan Jaringan Feedback

Jaringan feedback dari gambar diatas dapat dilihat bahwa elemen-elemen yang akan dibandingkan berada pada cluster-cluster $\mathrm{C} 2$ dan $\mathrm{C} 3$ yang dikenal dengan outer dependence. Selain itu juga ada elemen-elemen utama yang akan dibandingkan hubungan dengan dirinya sendiri, sehingga membentuk hubungan loop, kondisi ini disebut dengan istilah inner dependence.

Setiap elemen dalam cluster dapat berhubungan dalam cluster yang, dan dapat pula elemen cluster berhubungan dan memengaruhi elemen lain pada cluster yang berbeda.

Dalam ANP, seluruh kriteria harus diatur serta dibuat prioritas dalam jaringan yang didapat dari perbandingan sintesis. Kemudian dengan kriteria tersebut kita visualisasikan pengaruh dari kriteria atau elemen dalam jaringan.

\section{Prinsip (ANP)}

1. Prinsip Dekomposisi

Untuk masalah yang kompleks menjadi kerangka hirarki atau kerangka ANP yang terdiri dari jaringan-jaringan cluster.

2. Prinsip Penilaian Komparasi

Untuk melakukan perbandingan berpasangan (pairwise comparison) dari seluruh kombinasi elemen. Perbandingan ini dipakai untuk mendapatkan prioritas dari elemenelemen didalam suatu cluster yang dilihat dari cluster induknya.

3. Prinsip Komposisi Hirarkis atau Sintesis

Pertimbangan terhadap perbandingan berpasangan disintesiskan untuk memperoleh prioritas. Yang dilakukan dalam proses ini adalah: Menjumlahkan nilai dari setiap kolom matriks, dengan membagi setiap nilai kolom dengan total kolom yang ada untuk memperoleh normalisasi matriks. Menjumlahkan nilai dari tiap baris serta membaginya dengan sejumlah elemen untuk mendapatkan nilai reratanya.

\section{Sistem Pendukung Keputusan}

Sistem pendukung keputusan (Decission Support system) didefinisikan sebagai sistem informasi yang berguna membantu untuk mengambil senuah keputusan supaya lebih efektif dengan menggunakan model analitik dari data yang tersedia. Decision Support Systems (DSS) adalah satu-satunya perangkat lunak gratis yang mengimplementasikan ANP dan dikembangkan 
oleh tim pencipta metode, Thomas Saaty. Pengembangan dan mantainansinya disponsori oleh Creative Decisions Foundation.

\section{Kinerja Dosen}

Kinerja dosen adalah seorang dosen menghasil kinerja yang dicapai oleh seorang dosen, sesuai dengan tanggung jawab masing-masing dosen dalam rangka mencapai tujuan pendidikan secara legal, tidak melanggar hukum dan sesuai dengan norma atau etika. Dessler menyatakan enam cara yang bisa dilakukan untuk melakukan penilaian terhadap kinerja seseorang dosen yaitu: (satu) sumber penilaian didapat dari ketua progaram studi, (dua) penilaian teman sejawat, (tiga) penilaian dilakukan oleh komisi penilai ( BPM), (empat) penilaian diri yang dilakukan oleh yang dinilai, (lima) penilaian dilakukan oleh mahasiswa, dan (enam) penilaian umpan balik. Kinerja dosen yang diambil dalam penelitian ini hanya pada point (lima) yaitu penilaian dilakukan oleh mahasiswa terhadap dosen.

\section{METODE}

Penelitian ini menggunakan metodologi Analytic Network Process (ANP), data yang digunakan didapat dari hasil pengisian kuesioner dengan responden. Data disiapkan olah dalam ANP adalah variable penilaian responden terhadap masalah yang menjadi objek penelitian dalam skala numerik. Pemilihan Dosen sebagai obyek yang dinilai pada penelitian ini dilakukan secara purposive sample (sengaja) 5 sampai 10 dengan mempertimbangkan prestasi di tingkat program studi informatika. Pemilihan mahasiswa sebagai responden penilai dilakukan secara random dengan batasan responden tersebut pernah diajarkan beberapa matakuliah oleh dosen yang dijadikan sebagai objek dalam penelitian ini. Metode analisis ANP jumlah sampel/responden tidak digunakan sebagai patokan validitas. Pertanyaan dalam kuesioner ANP berupa penilaian mahasiswa terhadap dosen. Skala numerik 1-5 untuk mengunakan merupakan terjemahan dari penilaian verbal. Pengisian kuesioner oleh responden didampingi peneliti untuk menjaga konsistensi dari jawaban yang diberikan responden.

\section{HASIL DAN PEMBAHASAN}

Sistem pendukung keputusan kinerja dosen menggunakan ANP pada Universitas, kriteria tahap pertama dalam penunjang keputusan, dalam menentukan kinerja dosen untuk menggambarkan bagaimana Alternative dan kriteria yang dibuat, sistem pendukung keputusan meliputi Alternative dan kriteria serta standar penilaian yang terdiri dari kriteria dalam menentukan kinerja dosen yang meliputi Pendagogik, Profesional, Kepribadian, Sosial, penilaian kriteria. Sistem Pendukung keputusan kinerja dosen dengan metode ANP pada Universitas menggunakan Software SuperDicision versi 2.8. seperti pada Gambar 2. 


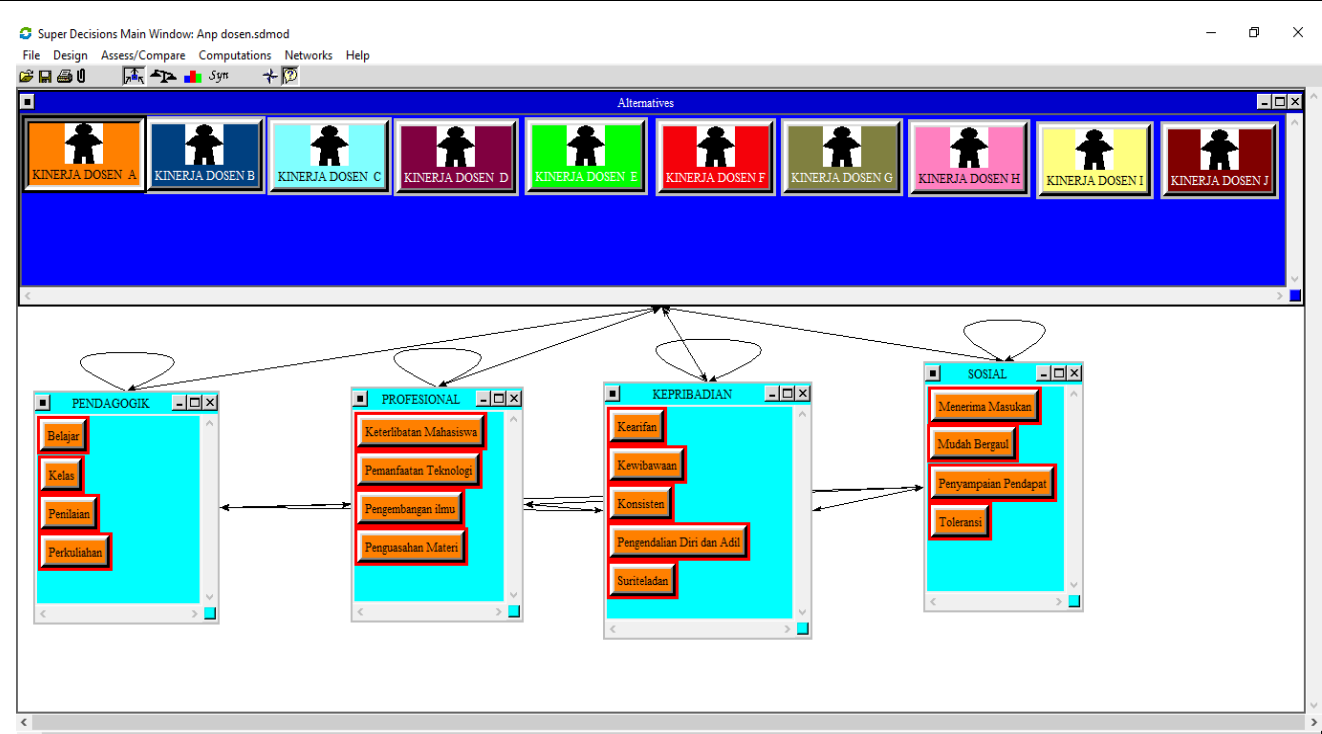

Gambar 2. Sistem pendukung keputusan kinerja Dosen

Berdasarkan gambar 2. Tentang Sistem Pendukung Keputusan Kinerja Dosen menggunakan 10 (sepuluh) sampel dosen teknik Informatika di Universitas. Sepuluh Dosen tersebut dianggap memiliki Kemampuan kompetensi terbaik oleh atasan diantara dosen lainnya. Untuk menilai kinerja kelima dosen tersebut peneliti menggunakan kuesioner yang disebar secara random kepada mahasiswa prodi informatika yang pernah diajarkan beberapa matakuliah oleh dosen tersebut.

Kuesioner yang digunakan dalam penelitian ini terdiri dari 4 (empat) kriteria dan masingmasing kriteria memiliki 4 (empat) sampai 5 (lima) subkriteria untuk dibandingkan.

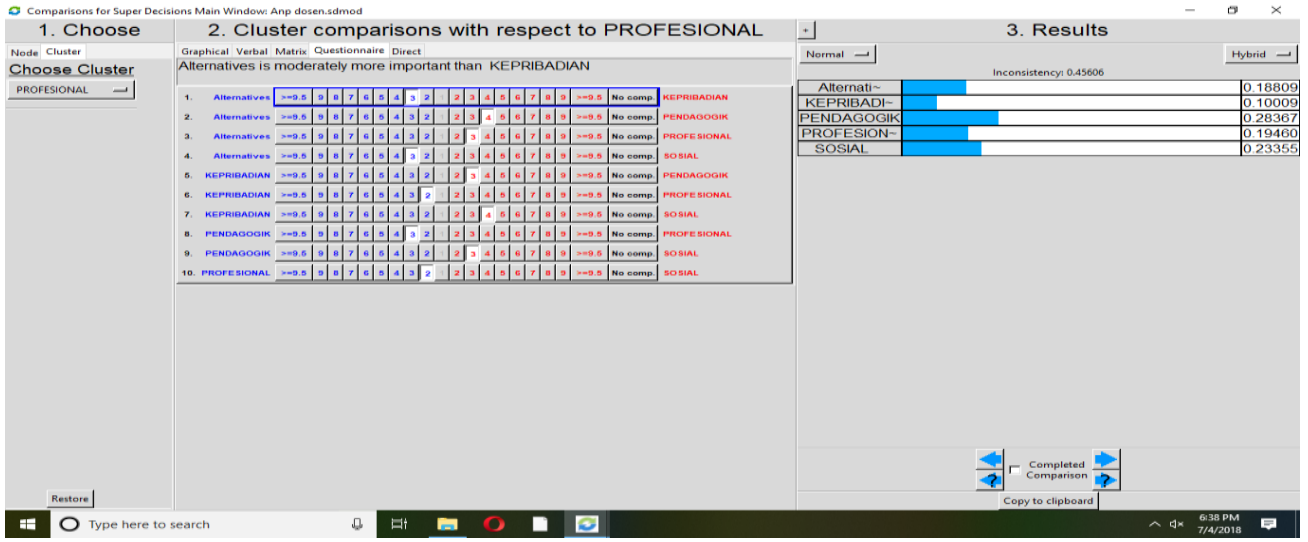

Gambar 3. Perbandingan antara alternatif dalam kriteria Kinerja Dosen.

Berdasarkan gambar 3. Tentang perbandingan alternative dalam kriteria kinerja dosen terlihat bahwa dosen B memiliki nilai tertinggi pada kriteria pedagogik yaitu dibagian pengajaran.

Dari Contoh bagian/cluster : Profesional Kinerja Dosen. Berikut prioritas kriteria Kinerja Dosen dalam cluster Profesional, dapat dilihat pada Gambar 4. 


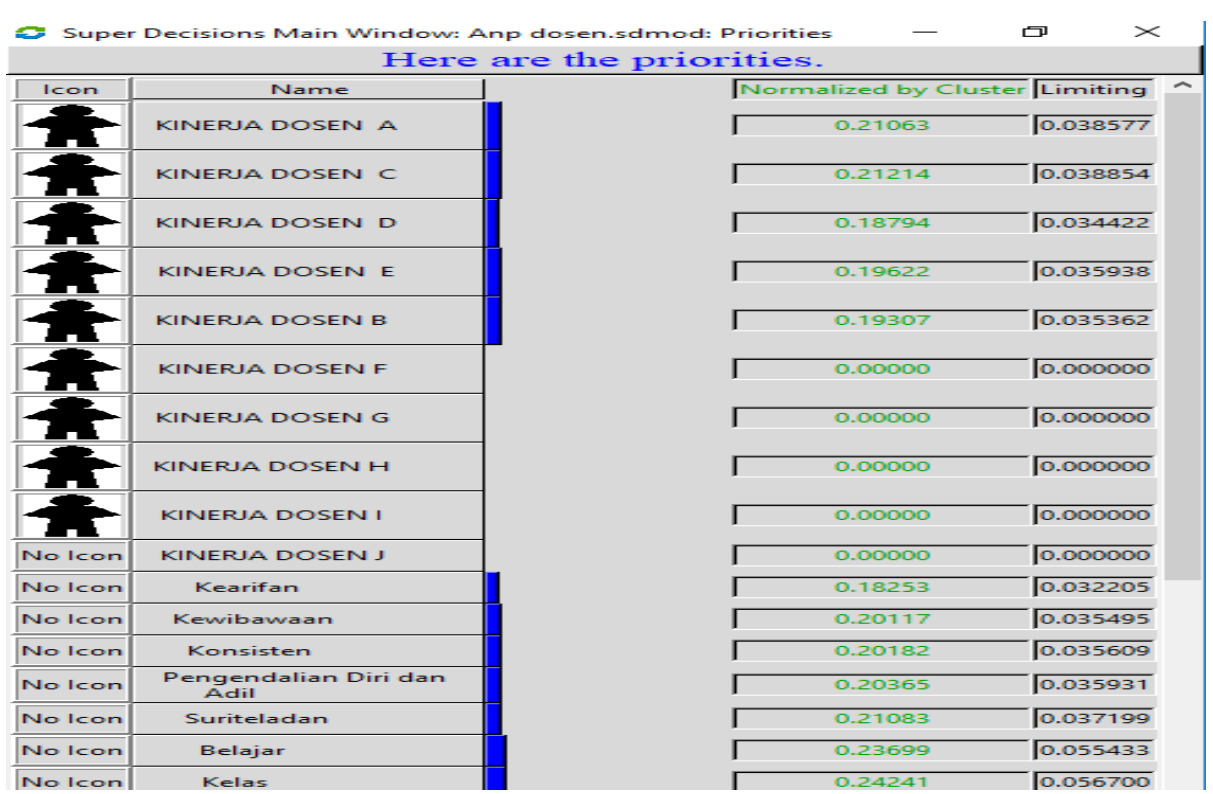

Gambar 4. Hasil Penilaian Prioritas kriteria Kinerja Dosen dalam cluster Profesional.

Berdasarkan gambar 4. Hasil Penilaian Prioritas kinerja Dosen dalam cluster professional didapat Alternative Rangking semua bagian/cluster dalam ANP yang bisa dilihat pada gambar5.

\section{Alternative Rankings}

\begin{tabular}{|c|c|c|c|c|c|}
\hline Graphic & Alternatives & Total & Normal & Ideal & Ranking \\
\hline \hline & KINERJA DOSEN A & 0.0300 & 0.1638 & 1.0000 & 1 \\
\hline \hline & KINERJA DOSEN C & 0.0261 & 0.1428 & 0.8718 & 5 \\
\hline \hline & KINERJA DOSEN D & 0.0269 & 0.1468 & 0.8965 & 4 \\
\hline \hline & KINERJA DOSEN E & 0.0285 & 0.1558 & 0.9512 & 2 \\
\hline \hline & KINERJA DOSEN B & 0.0280 & 0.1527 & 0.9322 & 3 \\
\hline & KINERJA DOSEN F & 0.0093 & 0.0509 & 0.3106 & 6 \\
\hline \hline & KINERJA DOSEN G & 0.0082 & 0.0445 & 0.2719 & 10 \\
\hline \hline & KINERJA DOSEN H & 0.0084 & 0.0458 & 0.2798 & 9 \\
\hline \hline & KINERJA DOSEN I & 0.0090 & 0.0490 & 0.2990 & 7 \\
\hline & KINERJA DOSEN J & 0.0088 & 0.0481 & 0.2935 & 8 \\
\hline
\end{tabular}

Gambar 5. Hasil Penelitian Prioritas Alternative Rangkings Kinerja Dosen menggunakan ANP pada Univeritas.

Berdasarkan hasil Penelitian dan kuesioner maka didapat tabel alternative ranking yang dapat dilihat hasil Penelitian Prioritas Alternative Rangking Kinerja Dosen menggunakan ANP pada Univeritas. Terlihat bahwa Dosen A memiliki ranking total penilaian tertinggi dalam semua kriteria kinerja dosen.

\section{PENUTUP}

Simpulan

Penelitian mendapatkan beberapa kesimpulan dari hasil sistem pendukung keputusan kinerja dosen dengan metode ANP pada Universitas, Bahwa tersedianya model Software Super Dicision sebagai berikut terdapat Alternative dan criteria. Dalam menentukan Alternative kinerja dosen dari semua bagian yang terkait dengan uraian kinerja dosen meliputi kriteria Pedagogik, Profesional, Kepribadian, Sosial. Kinerja dosen salah satu bagian untuk menunjang membangun semangat dosen melaksanakan TRIDHARMA Pada Universitas. Penelitian mendapatkan implementasi yaitu sistem pendukung keputusan ini dapat terlaksana dengan baik. 
Dan menurut hasil penelitian didapat bahwa Kinerja Dosen A mendapatkan Rangking 1 pada Sistem Pendukung Keputusan Kinerja Dosen Menggunakan Metode ANP pada Universitas.

\section{Saran}

Penelitian ini masih dalam sampel kecil dan hanya meneliti kinerja dosen dalam bidang pengajaran karena keterbatasan dari peneliti, oleh karena itu perlu dikembangkan penelitian lebih lanjut mengingat variabel kinerja dosen lebih kompleks dan luas.

\section{Ucapan Terimakasih}

Ucapan Terimakasih disampaikan kepada Direktorat Riset dan Pengabdian Masyarakat, Dirjen Penguatan Riset dan Pengembangan, Kementerian Riset, Teknologi dan Pendidikan Tinggi yang telah membiayai kegiatan Penelitian Dosen Pemula (PDP) Tahun 2018 dengan Judul:"SISTEM PENDUKUNG KEPUTUSAN KINERJA DOSEN MENGGUNAKAN METODE ANALYTICAL NETWORK PROCESS (ANP) PADA UNIVERSITAS". Terima kasih juga kepada LLDIKTI Wilayah III Jakarta dan Lembaga Pendidikan dan Pengabdian Masyarakat Universitas Indraprasta PGRI yang telah membantu kegiatan penelitian ini melalui kontrak Penelitian : Nomor 032/KM/PNT/2018, Tanggal 06 Maret 2018. Dan Surat Perjanjian/Kontrak Penelitian UNINDRA Nomor 0310/SKP.LT/LPPM/UNINDRA/III/2018, Tanggal 12 Maret 2018.

Peneliti mengucapkan banyak terima kasih kepada Prof.Dr. H. Sumaryoto (Rektor Universitas Indraprasta PGRI). Prof. Dr. sc. agr. Ir. Didik Sulistyanto (Rektor Universitas Budi Luhur) dan Dr. H. Dadang Solihin, SE., MA. (Rektor Universitas Darma Persada) Telah memberikan tempat penelitian Dosen Pemula. Semua pihak yang membantu Penelitian ini, kami Ucapkan Terima Kasih.

\section{DAFTAR PUSTAKA}

Gory dan Scott Morton, Simon, Anthony, Decision Support Framework, Memenuhi Karakteristik Rasional Dalam Pengambilan Keputusan, 1977

Henry, Susanto , Penerapan Metode Analytic Network Process dalam Membantu Perusahaan Travel Dalam Pemilihan Perusahaan, Karoseri ( Studi Kasus di Perusahaan CV. Citra Tiara), 2007

Thomas L,"The Essentials of the Analytic Network Process with Seven Example"Decision Making with Dependence and Feedback:The Super Decision Software,Thomas,L,Saaty, 2003

Saaty, TL, Pengambilan Keputusan Bagi Para Pemimpin: Proses Hirarki Analitik untuk Pengambilan Keputusan dalam Situasi yang Kompleks., Pustaka Binaman Pressindo, 1993

Vanny, Aplikasi Analytic Network Process (ANP) Pada Perancangan Sistem Pengukuran Kinerja ( Studi Kasus Pada PT. X), 2003

Aam Slamet Rusydiana \& Abrista Devi, "Analytic Network Process: Pengantar Teori dan Aplikasi”, SMART Publishing, Bogor, 2013.

Jurnal Keuangan dan Perbankan, Vol. 13, No.3 September 2009, hal. 359 - 372. Terakreditasi SK. No. 167/DIKTI/Kep/2007

Niemira Saaty, AnalyticProcess Model For FinancialCrisis Forecasting,Saaty, 2004.

sistem-pendukung-keputusan.http://lecturer.fikom.umi.ac.id/lilis/2016

Sertifikasi dosen, Buku I, Naskah Akademi, Kementrian Ristek Dikti, Jakarta, 2017

Superdecision, http://wwwSuperdecision.com (diakses Mei 2018) 